\title{
Has the introduction of the possibility to build a single-family house on the basis of notification really improved the development process? The analysis based on the example of the Capital City of Warsaw (Poland)
}

\author{
Sylwia Kołacińska ${ }^{1}$, Tomasz Zaborowski ${ }^{2}$ \\ ${ }^{1}$ Department of Architecture and Construction; Bielany District Office of Warsaw Capital City; \\ 29 S. Żeromskiego St., 01-882 Warszawa, Poland; \\ sylwiaw0793@gmail.com \\ ${ }^{2}$ Chair of Urban Geography and Spatial Planning; Faculty of Geography and Regional Studies; \\ University of Warsaw; 30 Krakowskie Przedmieście St., 00-927 Warszawa, Poland; \\ t.zaborowski@uw.edu.pl iD 0000-0001-9656-5169
}

\begin{abstract}
On 28 June 2015, an amendment to the Construction Law Act (Journal of Laws of 2018, item 1202, as amended) came into force, abolishing a requirement to obtain a building permit to construct or reconstruct a detached single-family residential building, which impact area is limited to the plot or plots on which it was designed, enabling its construction on the basis of a notification. This amendment was intended to simplify the investment process for the construction of single-family houses. This article is a contribution to the verification of this thesis. It analyses data on applications submitted to the Warsaw district offices within the period of 3 years of the amendment of the Construction Law. The data concerning notifications for Bielany and Białołęka districts was then juxtaposed with the data concerning building permits. The number of required formalities, the duration of both procedures, the percentage of positive decisions, and the frequency of using both procedures were compared. The results of the research undermine the thesis that the discussed change in the law has improved the investment process of construction of single-family houses.
\end{abstract} tion law

Keywords: notification, building permit, facilitation, single-family houses, construc- 


\section{Introduction}

Pursuant to the general rule articulated in Article 28.1 of the Act of 7 July $1994-$ Construction Law (hereinafter: Construction Law) [1], construction works may only be commenced on the basis of a decision on the building permit. In Article 29 of the Construction Law [1], the legislator included a catalogue of construction works, the performance of which does not require the building permit - a list of exceptions to the general rule, which according to legal doctrine is of a closed nature [14]. The provisions of Article 29 have been modified several times, as the legislator attempted to expand the catalogue of construction projects exempt from the obligation to obtain the building permit. The last radical change was made in the Act of 20 February 2015 amending the Construction Law and certain other acts [3].

Construction works indicated in Article 29 of the Construction Law [1] should be associated with legal regulations indicated in Article 30, which establishes the institution of the notification. Only the juxtaposition of these regulations provides the complete picture of the administrative formalities that an investor must undertake in order to legally carry out an investment project. Consideration of the notification does not take place by way of an administrative act, but through the so-called tacit consent of an authority, which in fact consists in not taking any action [2].

The competent architecture-construction administration body raises an objection if a notification concerns construction or performance of construction works subject to a requirement of obtaining a building permit, or if the project violates the provisions of the local spatial development plan or other regulations. The term raises an objection contained in the Act means that it does not depend on the authority's discretion, but instead they are obliged to raise an objection, if at least one of the prerequisites listed above occurs [2].

On 28 June 2015, the Act of 20 February 2015 amending the Construction Law and certain other acts came into force [3]. In the justification of the proposed act, it was indicated that the existing provisions are overly elaborate and lead to the investment process being too time-consuming [4]. Therefore, the main objective of the amendment was to shorten and simplify the procedure provided for in the Act. The amendment of the legislation was a step towards liberalising the formal requirements for the construction of single-family residential buildings. The main premise of the amending law was the abolition of the requirement to obtain the building permit decision for the construction or reconstruction of single-family residential buildings with an impact area entirely within the plot or plots on which they were designed. From the date of entry into force of the amendment, the investor has the right to choose whether to remain with the current procedure for obtaining a building permit or to make a notification.

According to the legislator, the changes were particularly sought by individual investors, who were pointing out that the complexity of the procedures should be adapted to the type of a building. They were hoping for shortening the duration of the proceedings and simplification of project documentation. In the justification of the draft amending act, it was noted that in 2013, approximately 75,000 decisions on building permits for single-family residential buildings were granted, which accounted for approximately $40 \%$ of all building permits issued. It was also pointed out that among the decisions on single-family development, in $40 \%$ of them the applicant was the only party to the proceedings [4]. 
As already mentioned, the exemption from the obligation to obtain the building permit does not mean the abandonment of administrative control. Pursuant to Article 30 Section 1 of the Construction Law [1], a construction project is subject to notification to the competent authority, which must be submitted prior to the intended date of commencement of the works. The replacement of the building permit decision with the institution of notification was the subject of many considerations by the Constitutional Tribunal of Poland. A critical approach was revealed, i. a. in the judgment of 20 April 2011, in which it was indicated that the extension of the scope of application of the notification institution is associated with insufficient influence of state authorities on ensuring public order and the possibility to enforce respect for public interest, as well as with the undermining of protection of property rights of third parties [5].

The slogan - "single-family houses upon notification" - was enthusiastically promoted by the media [6], [7]. According to the Ministry's calculations, investors of as many as 30,000 single-family buildings were to benefit from the new procedure each year [8]. According to the data, in approximately $40 \%$ of single-family building cases, there are no other parties than the applicant himself. Therefore, it was assumed that in as many cases, the building permit will be replaced with the notification [8].

\section{Literature on the subject}

The only scientific publication known to the authors relating to the discussed topic is that of M. Sługocka, and M. Bursztynowicz [4]. The authors are not familiar with other, especially analytical scientific publications on the subject. The discourse so far seems to be limited to the popular and specialist press. The discussed amendment to the Construction Law electrified the public opinion in 2015-2017, i.e. just before and after the change of regulations. Most newspaper articles from 2015 only introduced and discussed the new legislation [6], [7], [9]. Even then, however, the first articles appeared, suggesting a sceptical approach to the apparently favourable legal changes for investors [8]. On 27 February 2015, Dziennik Gazeta Prawna discussed controversies related to unclear rules for determining the area of impact of a facility [10]. In Rzeczpospolita on 3 September 2015, an analysis of the requirements and conditions of both variant legal procedures was presented, suggesting investors to soberly consider their advantages and disadvantages [11]. In retrospect, more and more criticism of the legislation introduced in 2015 can be observed. In an article dated 27 October 2017 [12], the amended provisions regarding the method of determining the area of impact of a facility were considered "unfortunate", while the institution of notification of construction of a single-family house itself was said to be "unpopular".

The subject of notifications was also taken up by Gazeta Wyborcza, where the journalists, a little over six months after implementation of the Act, were attempting to find an answer to the question why Poles do not benefit from such widely advertised simplification of procedures [20]. The issue was also raised in August 2016 in Dziennik Gazeta Prawna. At the time, one of the articles was given the headline: "Collapse of houses on notification" [21]. The editors wrote: "It was supposed to be simpler and faster. However, it turned out that investors do not need such simplifications". When preparing the amendment, it was assumed that about 30 thousand investors would benefit from the simplified procedure within a year; in reality, there were 5 times less of them [21]. In an article published in February 2017, the journalists of Rzeczpospolita also concluded that despite the introduction of the simplified procedure, it is still more popular to build single-family houses 
with a building permit [22]. The topic also appeared in an article published in November 2018 on the website of Rzeczpospolita with the title "Villa on notification is still a great rarity" [23]. The author, referring to data from the Main Construction Supervision Office, emphasised that investors prefer to build based on a building permit, as this is connected with a lower investment risk [23].

\section{Research questions and methods}

The aim of the study was to answer the following general research question (GQ): Did the amendment to the provisions of the Construction Law Act, allowing the construction of detached single-family residential buildings based on a notification, contribute to the improvement of the investment process for the erection of single-family residential buildings in the examined period in the Capital City of Warsaw? In order to answer this general question, the following auxiliary questions (AQ) were posed:

AQ1: Are there fewer formalities for the investor to complete in the notification procedure?

AQ2. How many notifications for the construction of detached single-family dwellings were accepted on the territory of the Capital City of Warsaw in the analysed period?

AQ3: What was the most common reason for objections to these notifications?

AQ4: Were investors more likely to use the notification or building permit procedure?

AQ5: Has the duration of the administrative procedure for starting construction work been reduced in real terms?

AQ6: Which procedure - the notification or building permit - was more likely to result in a positive outcome for investors?

The time scope of the study covered the period of three years from the date of entry into force of the Construction Law Amendment Act [3], i.e. 28 June 2015 to 28 June 2018. The substantive and spatial scopes corresponded to the two-stage form of the study. At first, an analysis was performed on the data concerning notifications for the construction of single-family residential buildings, which in the given period were received by all 18 district offices of capital city of Warsaw. On this basis, answers to the auxiliary questions AQ1, AQ2, AQ3 were provided. Then, a comparison was made on the data on notifications versus building permits of two sample districts - Bielany and Białołęka. As a result, it allowed the authors to answer auxiliary questions AQ4, AQ5 and AQ6.

\section{Legal status}

During the proceedings for the granting of a building permit, the following parties are involved: an investor and owners, perpetual users or managers of properties located in the area affected by the facility. It is therefore important to determine a building impact area. According to the definition set out in Art. 3, section 20 of the Polish Construction Law Act, the area of influence of a facility is "the area designated in the vicinity of the facility on the basis of separate provisions introducing associated restrictions on the development of the facility, including the development of a given area." [1]. Such an area should be determined individually for the needs of each specific case and consider the form, structure, and characteristic features of a designed building, as well as the way the land surrounding the planned investment is developed [13]. Therefore, the designer, basing on the regula- 
tions, jurisprudence, and own practice, as well as taking into account the development of the adjacent plots, is obliged to decide whether the impact area of a facility is limited to the boundaries of the plot on which it is designed, or not, and then include a note to that effect in the project.

The definition of the area of impact poses certain problems. There are numerous difficulties in applying it in practice as the legislator does not indicate regulations governing the determination of the area of impact of a facility. As early as in 2011, the Constitutional Tribunal in Poland attempted to clarify the issue of the area of impact, concluding that the area of impact is determined by detailed provisions of the law, which set out the restrictions regarding fire protection, noise, environmental protection, technical and construction issues, and in particular the regulations regarding the distance of the facility from the property boundaries, as required by law [5].

There is no doubt that this list includes provisions included in the Regulation of the Minister of Infrastructure of 12 April 2002 on technical requirements to be met by buildings and their location [15], [14]. For example, $\S 13(1)$ of this regulation [15] specifies minimum distances of a building with rooms intended for human occupation from other objects, so that it is possible to light the rooms naturally. The jurisprudence repeatedly emphasises the fact that separate regulations do not only include the rules listed in the above-mentioned regulation. These regulations also include rules concerning environmental protection, protection of monuments, nature protection, water law, aviation law, as well as executive directives to the acts [16].

However, one cannot agree with the thesis that if a construction project complies with the technical and construction regulations, it does not have any impact on the surrounding properties. Such an approach would lead to a statement that the impact of a construction object occurs only in a situation where technical and construction regulations are violated. Meanwhile, a decision on a building permit should not be issued for an unlawful investment at all. Consequently, the area of a building's impact cannot be equated with the investor's compliance with the requirements set forth in the technical and construction regulations. It should also be emphasised that the impact area of a facility refers both to the developed and undeveloped land. Restrictions may arise during changes in the manner of development of the adjacent areas. Moreover, the area does not have to include only the plots directly adjacent to the property on which the investment is planned [17]. In fact, single-family detached houses developed in the vicinity of other buildings can always interact to some extent with existing buildings [18].

Table 1 synthesises the differences in the mechanism of building permit and construction notification of a detached single-family residential building. The comparison was made on the basis of the regulations resulting from the Construction Law. 
Table 1. Comparison of building permit and notification procedures for a detached single-family residential building. Source: authors'own study

\begin{tabular}{|c|c|c|}
\hline Stage & Building permit & Notification \\
\hline $\begin{array}{l}\text { Annexes to the application } \\
\text { required by the law }\end{array}$ & \multicolumn{2}{|c|}{$\begin{array}{l}\text { Three copies of the project together with opinions, agreements, } \\
\text { permits, and other documents required under separate regulations }\end{array}$} \\
\hline $\begin{array}{l}\text { Decision on development condi- } \\
\text { tions (in the absence of a plan) }\end{array}$ & \multicolumn{2}{|c|}{ Required } \\
\hline Parties of the proceedings & $\begin{array}{l}\text { Involvement of parties to } \\
\text { proceedings }\end{array}$ & $\begin{array}{l}\text { No need for involvement of } \\
\text { parties to proceedings }\end{array}$ \\
\hline $\begin{array}{l}\text { Completion of the procedure } \\
\text { (positive outcome for the } \\
\text { investor) }\end{array}$ & $\begin{array}{l}\text { Issuing of a building permit } \\
\text { decision }\end{array}$ & $\begin{array}{l}\text { Acceptance of notification by } \\
\text { a tacit consent }\end{array}$ \\
\hline $\begin{array}{l}\text { Completion of the procedure } \\
\text { (negative outcome for the } \\
\text { investor) }\end{array}$ & $\begin{array}{l}\text { Issuing of a decision to refuse to } \\
\text { grant a building permit }\end{array}$ & Objection by decision \\
\hline $\begin{array}{l}\text { Appeal (positive outcome for the } \\
\text { investor) }\end{array}$ & $\begin{array}{l}\text { Appeal against the decision } \\
\text { within } 14 \text { days }\end{array}$ & No means of appeal \\
\hline $\begin{array}{l}\text { Appeal (negative outcome for the } \\
\text { investor) }\end{array}$ & \multicolumn{2}{|c|}{ Appeal against the decision within 14 days } \\
\hline Duration of the procedure & Max 65 days* & Max 21 days** \\
\hline Validity & 3 years $* * *$ & 3 years $* * * *$ \\
\hline
\end{tabular}

* The time limit of 65 days shall not include periods prescribed by law for the performance of specific acts, periods during which proceedings are suspended or periods of delay caused by the fault of a party or by reasons beyond the control of the authority.

** The obligation to remedy the deficiencies in the dossier shall interrupt the time limit.

*** The building permit decision shall expire if construction has not commenced within 3 years from the date on which the decision became final or construction has been interrupted for more than 3 years.

**** If construction works have not commenced before the expiry of 3 years from the deadline specified in the notification for their commencement, they may commence after a new notification has been submitted.

The data presented above enables us to answer the auxiliary research question AQ1 posed at the beginning: are there fewer formalities to be fulfilled by an investor in the notification procedure? The answer is no. When planning the construction of a residential building based on a notification, the investor is obliged to provide the same architectural documentation as for a building permit. In both cases, for the areas where local land-use plans [miejscowy plan zagospodarowania przestrzennego] have not been adopted, an ad-hoc, auxiliary planning permit [decyzja o warunkach zabudowy] is also required. The number and type of attachments required by the architectural and construction administration depends, among others, on the location of an investment or its designation in the applicable local land-use plan. For example, if a planned building is to be erected on an agricultural plot, it will always be necessary to present the position of the competent authority on excluding this land from agricultural production [3]. 


\section{Results of the study}

\subsection{Analysis of construction notifications for single-family dwellings}

From 28 June 2015 (entry into force of the Act of 20 February 2015 amending the Construction Law and certain other acts [3]) until 28 June 2018, all 18 districts of the capital city of Warsaw received 537 construction notifications for single-family residential buildings, (Table 1) ${ }^{1}$.

Table 2. Number and completion of the notification procedure for detached single-family residential buildings in individual districts of the Capital City of Warsaw in the period from 28 June 2015 to 28 June 2018. Source: authors'own study

\begin{tabular}{lllll}
\hline District & $\begin{array}{l}\text { Number of notifi- } \\
\text { cations }\end{array}$ & Tacit consent & Objection & $\begin{array}{l}\text { Notification } \\
\text { withdrawn }\end{array}$ \\
\hline Bemowo & 10 & 3 & 3 & 4 \\
\hline Białołęka & 110 & 55 & 20 & 35 \\
\hline Bielany & 16 & 8 & 7 & 1 \\
\hline Mokotów & 16 & 6 & 10 & 0 \\
\hline Ochota & 0 & 0 & 0 & 0 \\
\hline Praga-Południe & 2 & 1 & 1 & 0 \\
\hline Praga-Północ & 0 & 0 & 0 & 0 \\
\hline Rembertów & 29 & 21 & 7 & 1 \\
\hline Śódmié́cie & 0 & 0 & 0 & 0 \\
\hline Targówek & 19 & 9 & 6 & 4 \\
\hline Ursus & 9 & 4 & 3 & 2 \\
\hline Ursynów & 45 & 14 & 22 & 25 \\
\hline Wawer & 181 & 70 & 86 & 4 \\
\hline Wesoła & 23 & 14 & 5 & 14 \\
\hline Wilanów & 44 & 26 & 4 & 2 \\
\hline Włochy & 28 & 19 & 7 & 0 \\
\hline Wola & 3 & 1 & 2 & 1 \\
\hline Żoliborz & 2 & 0 & 1 & 102 \\
\hline Total & 537 & 251 & 178 & \\
\hline
\end{tabular}

Fig. 1 presents the spatial distribution of notifications on the map of Warsaw with division into districts.

1 The data were collected independently. 


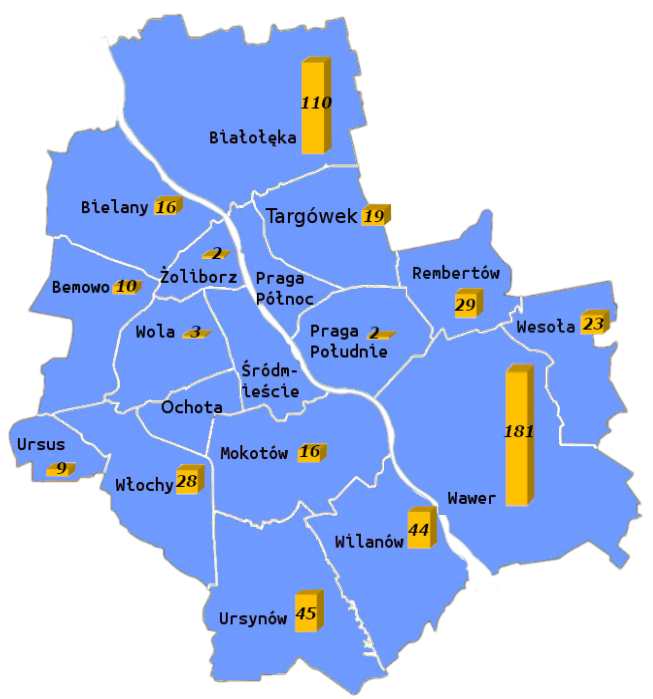

Fig. 1. Number of notifications of detached single-family residential buildings in individual districts of the Capital City of Warsaw in the period from 28 June 2015 to 28 June 2018. Source: authors'own study

Fig. 2 and Table 2 present the outcome of processing of construction notifications of detached single-family residential buildings in the period from 28 June 2015 to 28 June 2018 by districts of the capital city of Warsaw.

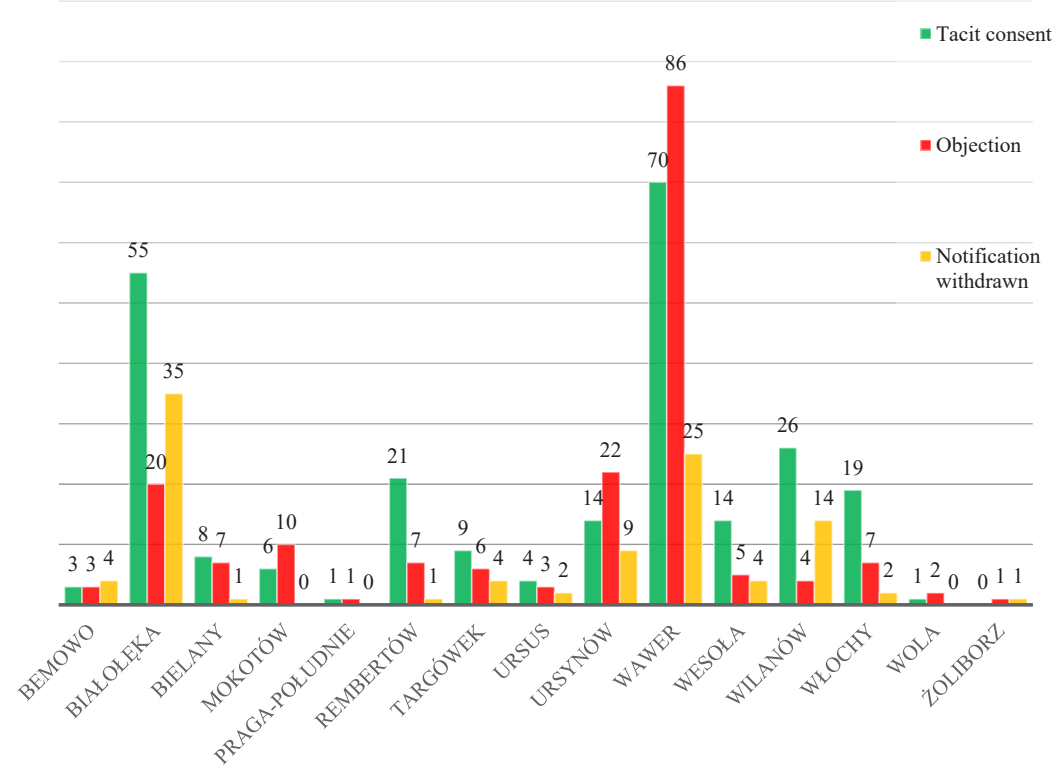

Fig. 2. Number of accepted notifications, withdrawn notifications, and objections to notifications of construction of detached single-family residential buildings in individual districts of the Capital City of Warsaw in the period from 28 June 2015 to 28 June 2018. Source: authors'own study 
The way of completing of the notification procedure in the whole city is shown in Table 3 and Fig. 3.

Table 3. Number of accepted notifications, withdrawn notifications, and objections to notifications of construction of detached single-family residential buildings in the capital city of Warsaw in the period from 28 June 2015 to 28 June 2018. Source: authors'own study

\begin{tabular}{ll}
\hline Completion of the procedure of notification & Number \\
\hline Objection & 184 \\
\hline Withdrawn & 102 \\
\hline Tacit consent & 251 \\
\hline
\end{tabular}

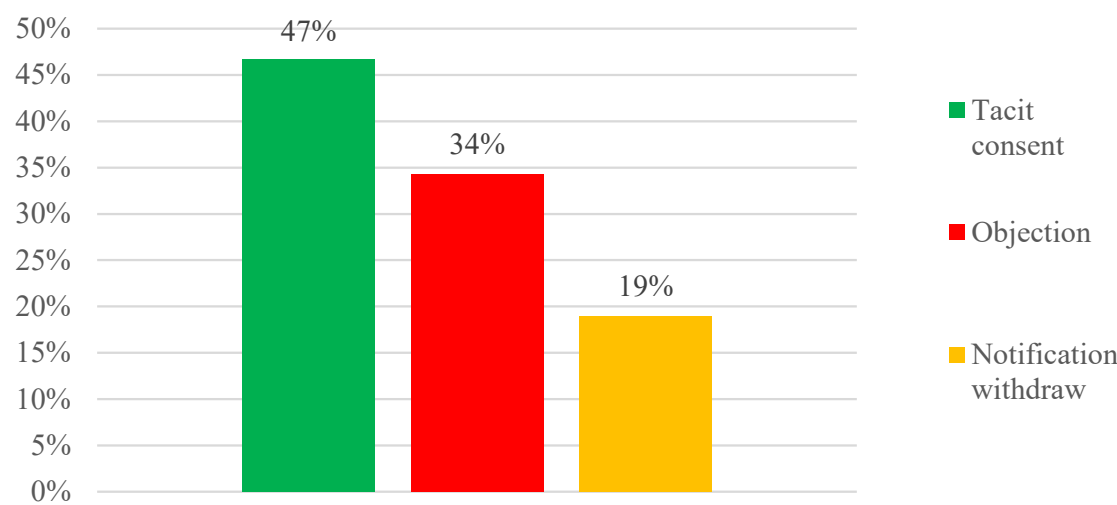

Fig. 3. Percentage of accepted notifications, withdrawn notifications, and objections to notifications of construction of detached single-family dwellings in the capital city of Warsaw between 28 June 2015 and 28 June 2018. Source: authors'own study

\subsection{Analysis of objections to construction notifications of single-family residential buildings}

Since accepted notifications for the construction of detached single-family dwellings accounted for less than $50 \%$ of all applications submitted, this subsection focuses on identifying the reasons for objections. In order to obtain the answer, almost all objection decisions issued by individual districts between 28 June 2015 and 28 June 2018 were analysed, i.e. 148 objection decisions (out of 184 issued). The exception is the district of Wawer, where out of 86 decisions issued, it was possible to access only 50 of them.

There is no single, discernible trend concerning the reasons for objections issued by individual district offices of the Capital City of Warsaw. Among 4 out of 15 districts: Białołęka, Mokotów, Rembertów, Wawer, the most frequent reason was the impact area of a designed facility extending beyond the boundary of an development plot. The districts of Praga-Południe, Ursus and Wola submitted objections only due to the lack of timely completion of missing information indicated in the decision (Fig. 4). 


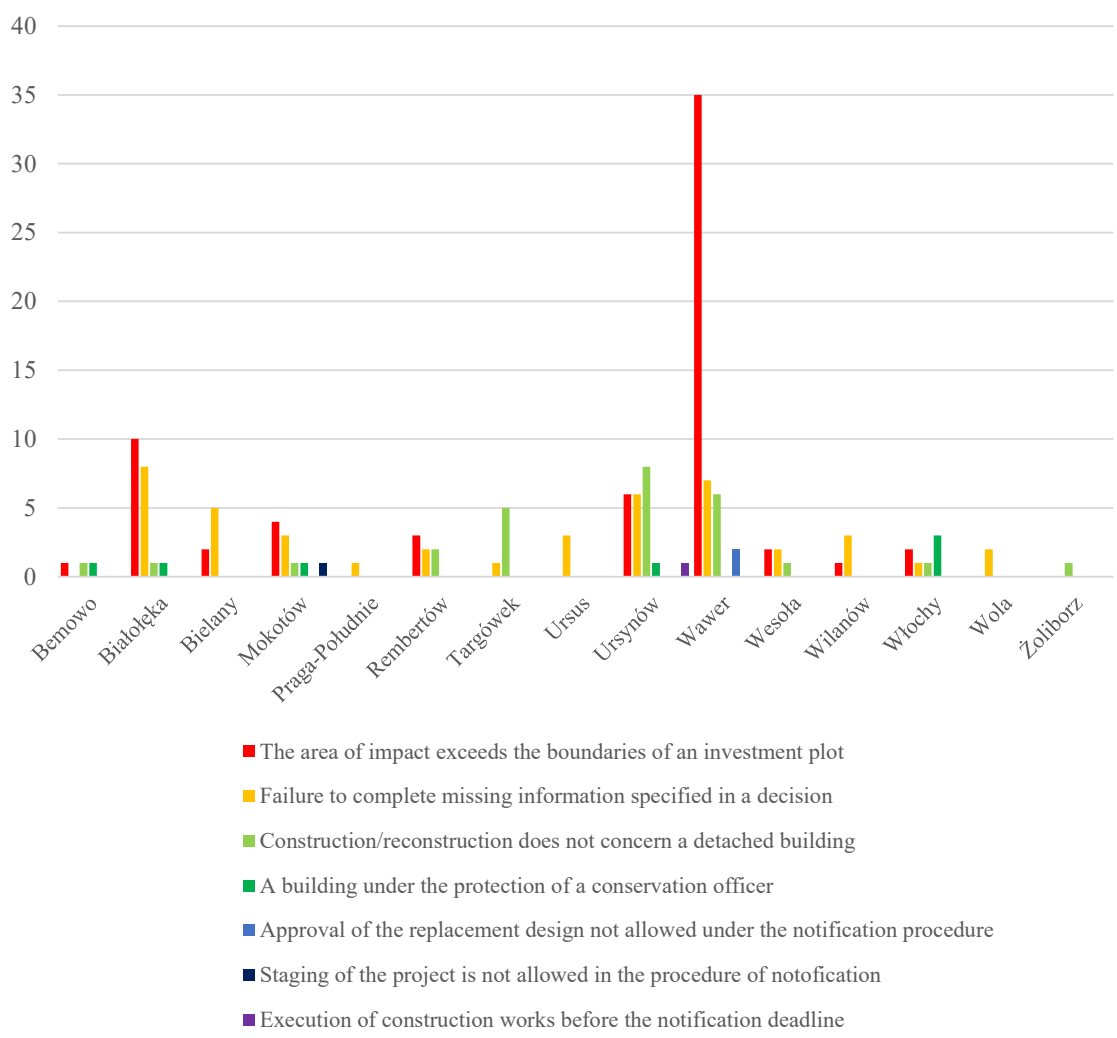

Fig. 4. Reasons for objections to notifications for detached single-family dwellings submitted between 28 June 2015 and 28 June 2018 in individual districts of the City of Warsaw. Source: authors'own study

Table 4 summarises the reasons for objections to notifications in the whole city.

Table 4. Reasons for objections to notifications of detached single-family residential buildings submitted between 28 June 2015 and 28 June 2018 in the Capital City of Warsaw. Source: authors'own study

\begin{tabular}{ll}
\hline Reason for objection & Number \\
\hline Construction/reconstruction does not concern a detached building & 27 \\
\hline A building under the protection of a conservation officer & 7 \\
\hline Staging of the project is not allowed in the procedure of notification & 1 \\
\hline Failure to complete missing information specified in a decision & 44 \\
\hline The area of impact exceeds the boundaries of an investment plot & 66 \\
\hline Execution of construction works before the notification deadline & 1 \\
\hline Approval of the replacement design not allowed under the notification procedure & 2 \\
\hline Total & 148 \\
\hline
\end{tabular}

The presented data enable answering the auxiliary research question AQ3: what was the most frequent reason for filing objections to notifications? The most common reason for objections to notifications of construction of detached single-family residential buildings in 
the period from 28 June 2015 to 28 June 2018 in the capital city of Warsaw was the impact zone of a designed building exceeding the boundaries of an investment plot. In $44 \%$ of the decisions subject to examination, an architecture and construction administration body (after analysing an investment project presented in the design) disagreed with a designer, finding that the area of impact of the building was not enclosed within the boundaries of a plot on which it was designed. A large share among analysed objections were also those, which were issued due to failure to remedy indicated irregularities within the time specified by the administrative body (Fig. 5). It is worth noting that such a situation occurs, if after checking the application submitted together with the architecture-construction design, the authority finds a violation of regulations. In such case, the authority calls on the investor to remove the irregularities, adjusting the deadline to the nature and scope of the listed deficiencies. In the notification procedure, the provisions on general administrative proceedings do not apply, so if there are difficulties in submitting the required documentation, the investor cannot request a suspension of the proceedings.

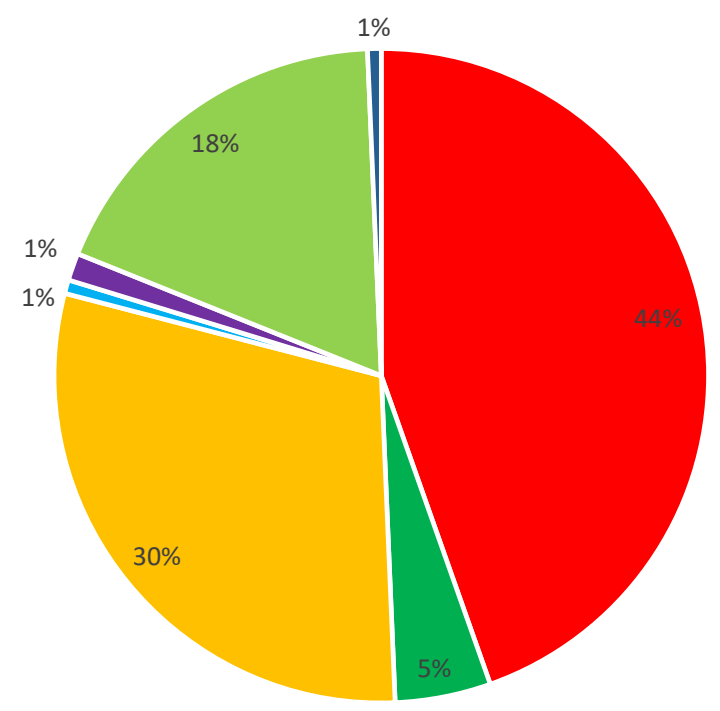

- The area of impact exceeds the boundaries of an investment plot

- A building under the protection of a conservation officer

- Failure to complete missing information specified in a decision

- Execution of construction works before the notification deadline

- Approval of the replacement design not allowed under the notification procedure

- Construction/reconstruction does not concern a detached building

- Staging of the project is not allowed in the procedure of notification

Fig. 5. Reasons for objections to notifications of detached single-family residential buildings submitted between 28 June 2015 and 28 June 2018 in the Capital City of Warsaw (in \%). Source: authors'own study 


\subsection{Comparison of construction notifications and building permits in selected districts}

To give more accurate picture of the scale and possible benefits of using the notification procedure for construction of detached single-family dwellings, a comparison was made of the data in relation to building permits. The comparison was made for two districts: the leftbank Bielany district and the right-bank Białołęka district (Fig. 6), for the period from 28 June 2015 to 28 June 2018. Data for the period of 1 January 2016-28 June 2018 are taken from the search engine of the Main Construction Supervision Office [19]. Data for the period from 28 June 2015 to 31 December 2016 were obtained directly from the Bielany and Białołęa district offices.

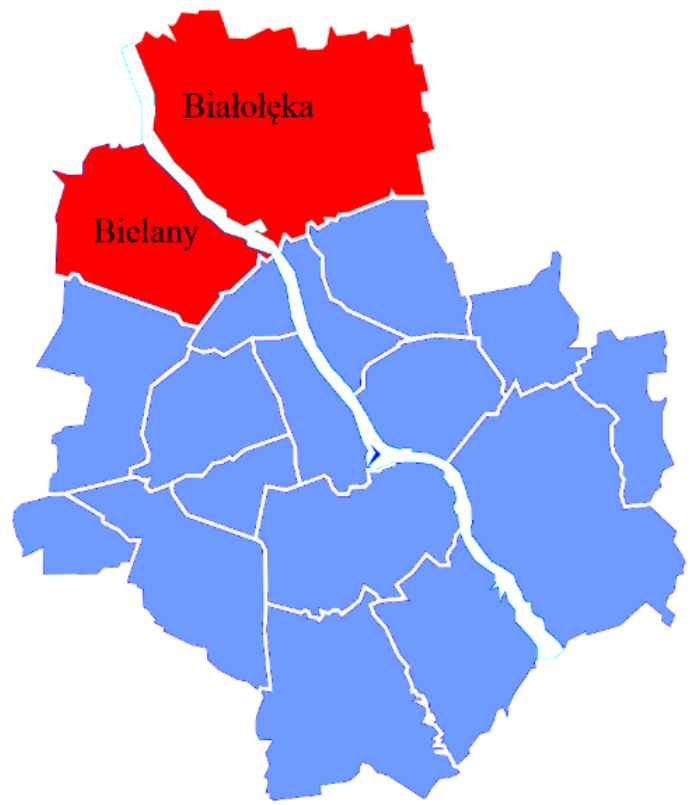

Fig. 6. Location of Bielany and Białołęka districts within the area of the Capital City of Warsaw. Source: authors' own study

In Bielany district, during the same time investors used the notification procedure much less frequently than the traditional building permit procedure. During the period of 3 years, the district office received only 16 notifications regarding construction of single-family residential buildings, while the number of applications for a building permit was almost 7 times higher, i.e. 108 (Fig. 7). 


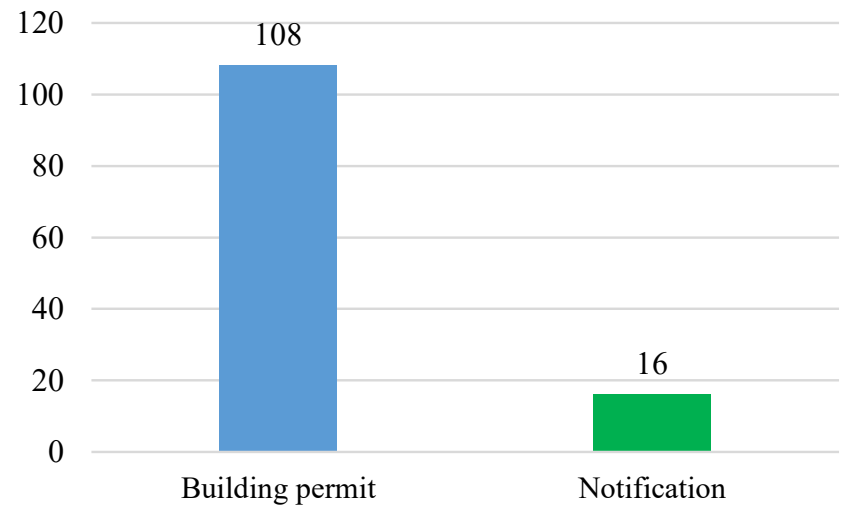

Fig. 7. Comparison of the number of notifications and applications for building permits for construction of detached single-family residential buildings in Bielany district between 28 June 2015 and 28 June 2018. Source: authors' own study

In the analysed period in Białołęka district there is also a noticeable difference in the number of notifications and applications for building permits for construction of detached single-family houses. During the period of 3 years, as many as 338 investors used the building permit procedure, while only 110 used the notification procedure (Fig. 8).

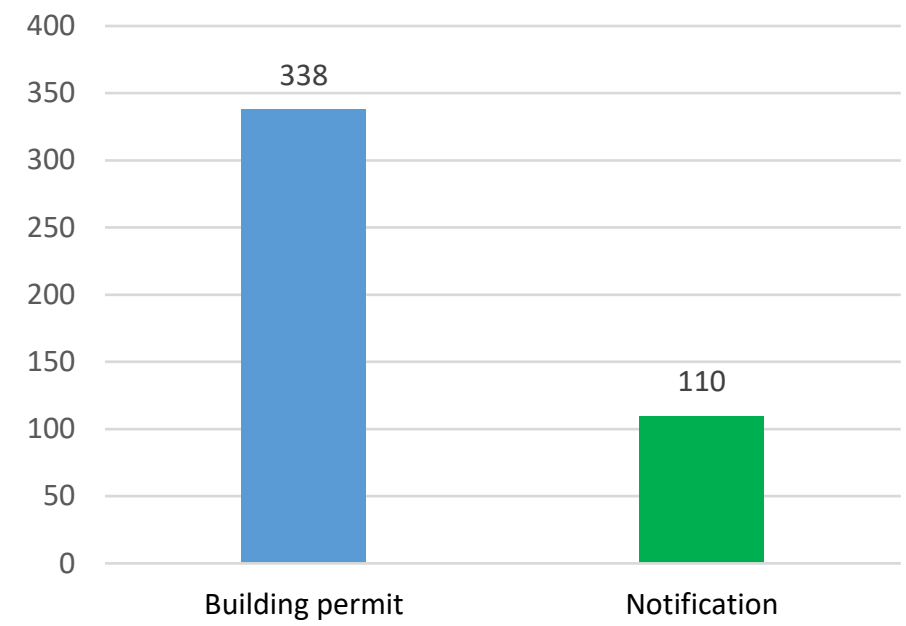

Fig. 8. Comparison of the number of notifications and building permits for construction of detached single-family residential buildings in Białołęka district between 28 June 2015 and 28 June 2018. Source: authors' own study

Based on the data presented, it is possible to conclude that in both districts there is a tendency to carry out developments based on a building permit (auxiliary question AQ4). 


\subsection{Duration of procedure in Bielany and Białołęka districts of Warsaw}

Another aspect analysed was the duration of procedures. The regulations explicitly indicate impassable time limits, however, in specific situations they may be extended or shortened. In the period of 3 years that was studied, the legal regulations concerning processing of notifications were subject to changes. From June 2015 to January 2017, a deadline of 30 days applied. Since January 2017, the period has been shortened and, to date, the notification must be processed in no more than 21 days.

The proceedings concerning a building permit cannot last longer than 65 days, however, this period does not include deadlines stipulated by law to perform certain actions, periods when proceedings are suspended, and periods of delays caused by a fault of a party or reasons beyond the control of the authority. Such situations include, among the others, the time from the moment of imposing on the investor, by way of a decision, the obligation to complete the construction designs to the moment of submitting the corrected documentation.

In order to provide a clear picture of the duration of both procedures in Bielany and Białołęka districts, the periods were divided as follows: from 1 to 30 days, from 31 to 60 days, from 61 to 90 days, and more than 91 days. For the purpose of research only the data related to the situation when the investor receives a positive decision for himself, i.e. the application is accepted with a tacit consent or a building permit is issued, were included. The results of the research illustrate how long the procedure allowing for commencement of construction works based on a notification and a building permit actually took.

In the analysed period almost all applications in Bielany district were examined in less than 30 days. Only one application received the tacit approval after a period of two months, which was probably due to the obligation on the investor to supplement the irregularities in the project documentation submitted with the application, or formal deficiencies in the application itself (Fig. 9).

Proceedings for granting a building permit in Bielany district, which ended with a positive decision in less than 30 days, accounted for only $5 \%$. Comparatively most applications were processed within a period between 31 and 60 days. The longest, i.e., more than three months, took the proceedings concerning $21 \%$ of the permits (Fig. 9).

The data presented shows that investors in Bielany district who opted for the notification procedure in the period between 28 June 2015 and 28 June 2018 were able to start construction much faster than investors who have decided to apply for building permit. 


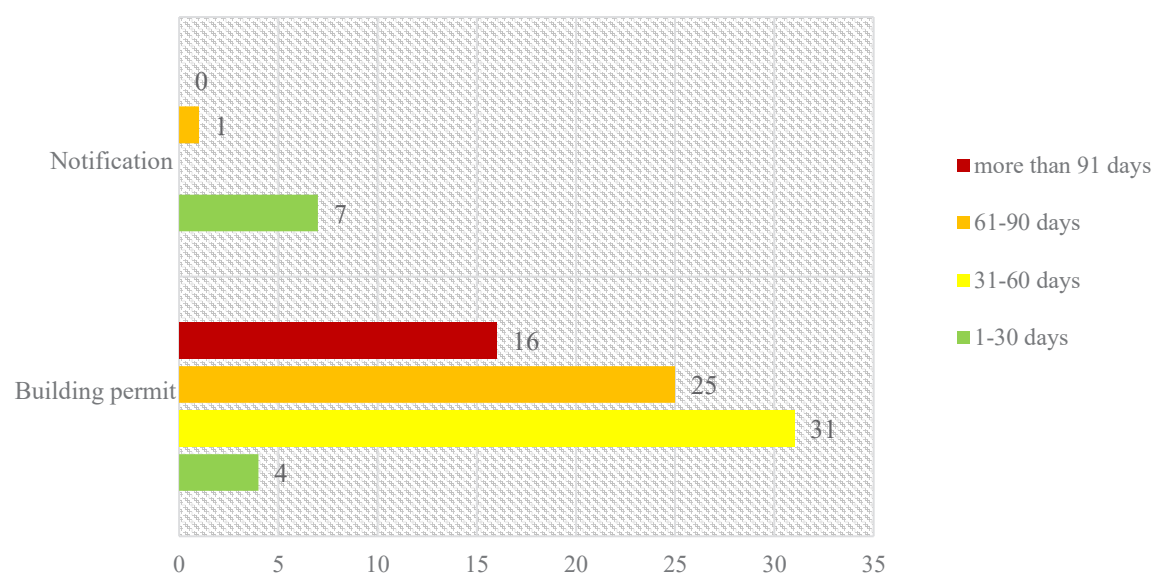

Fig. 9. Duration of the procedure for accepting notifications and obtaining building permits for detached single-family residential buildings in Bielany district in the period from 28 June 2015 to 28 June 2018. Source: authors'own study

Unlike in Bielany district, in Białołęka district notifications were most often processed within one to two months. In the period not exceeding 30 days, only $14 \%$ of the applications received tacit approval (Fig. 10). In most cases investors in Białołęka were obliged to complete missing elements in the notification or irregularities in the architectural documentation, which resulted in lengthening the procedure.

As in the case of notifications, investors in Białołęka had to wait longer to obtain a building permit than those in Bielany. Only $4 \%$ of applicants obtained a building permit in less than one month, $26 \%$ of them waited more than a month, and $32 \%$ more than 2 months (Fig. 10). Comparatively most investors received a building permit only after about 3 months. The prolongation of the proceedings could be caused by the necessity to fill in irregularities, obtaining exclusion of land from agricultural production, periods of suspension of proceedings or e.g. the obligation to agree the investment with a conservator of monuments.

The presented data show that in Białołęka district, investors choosing the notification procedure could most often start construction work after 31-60 days from submission of the application. When choosing the traditional form of the building permit, most investors had to wait more than 60 days. In summary, in the period between 28 June 2015 and 28 June 2018, the more favourable (in terms of waiting time) procedure for Białołęka investors was the construction notification. 


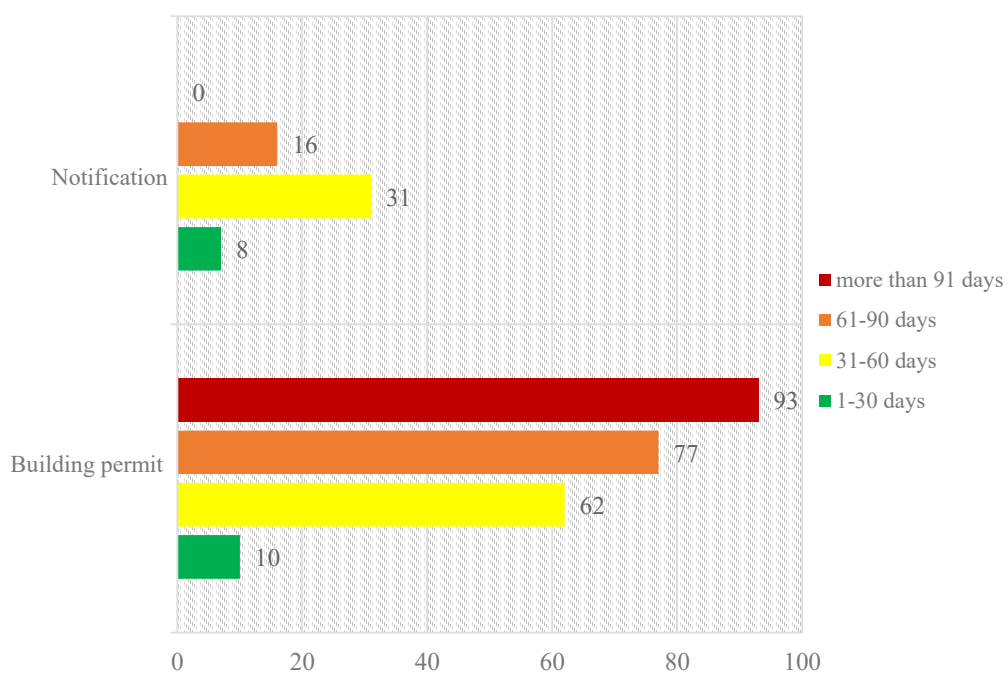

Fig. 10. Duration of the procedure for accepting notifications and obtaining building permits for detached single-family residential buildings in Białołęa district in the period from 28 June 2015 to 28 June 2018. Source: authors' own study

Based on the above data, it is possible to answer the auxiliary research question AQ5 in such a way that, within the examined scope, the construction notification procedure enabled faster commencement of construction of detached single-family residential buildings.

\subsection{The outcome of the procedure in Bielany and Białołęka districts}

According to the current regulations, the notification procedure may end with a tacit consent of the authority, filing of an objection by way of a decision or withdrawal (marked on the charts (Fig. 11 and 12) and in the tables 5 and 6 as "other"). In the case of the building permit, the situation is slightly more complicated as we are dealing here with administrative proceedings, regulated not only by the provisions of the Construction Law [1], but above all, by the Code of Administrative Procedure [24]. In the analysed data the following possibilities were noted: issuance of the positive decision, issuance of the negative decision, and (marked on the charts (Fig. 11 and 12) and in the Tables 5 and 6 as "other") leaving the application unconsidered, issuance of a discontinuance decision, and suspension of proceedings. The data presented in the form of the following Tables 5 and 6 and charts (Fig. 11 and 12) allow for obtaining information which of the procedures more often ended with a positive resolution for the investors.

Table 5. Completion of construction notification procedures and proceedings to obtain building permits for detached single-family residential buildings in Bielany district in the period from 28 June 2015 to 28 June 2018. Source: authors'own study

\begin{tabular}{llll}
\hline Building permit & & Notification & \\
\hline Positive decision & 76 & Tacit consent & 8 \\
\hline Negative decision & 8 & Objection & 7 \\
\hline Other & 24 & Other & 1 \\
\hline Total & 108 & Total & 16 \\
\hline
\end{tabular}




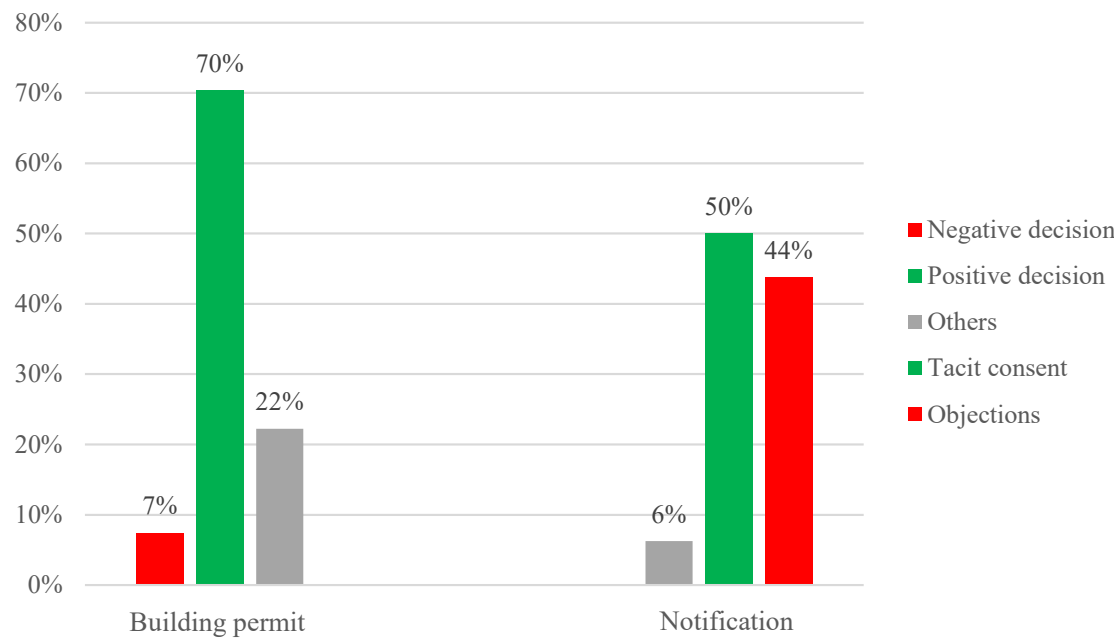

Fig. 11. Outcome of proceedings of construction notifications and proceedings to obtain building permits for detached single-family residential buildings in Bielany district in the period from 28 June 2015 to 28 June 2018. Source: authors' own study

In the Bielany district, only half of the notifications for the construction of detached single-family residential buildings received by the office between 28 June 2015 and 28 June 2018 were accepted by a tacit consent. Objections were raised against $44 \%$ of the notifications. Proceedings for obtaining a building permit in Bielany district resulted in a positive decision in $70 \%$ of the cases. Only $7 \%$ of investors received a negative decision (Fig. 11).

Having compared the above data, it can be concluded that in Bielany district investors who decided to build a detached single-family house based on a building permit were more often granted a positive decision than in case of submitting a construction notification.

Table 6. Completion of procedures for construction notifications and proceedings for obtaining building permits for detached single-family residential buildings in Białołęa district in the period from 28 June 2015 to 28 June 2018. Source: authors' own study

\begin{tabular}{llll}
\hline Building permit & & Notification & \\
\hline Positive decision & 242 & Tacit consent & 55 \\
\hline Negative decision & 19 & Objection & 20 \\
\hline Other & 77 & Other & 35 \\
\hline Total & 338 & Total & 110 \\
\hline
\end{tabular}




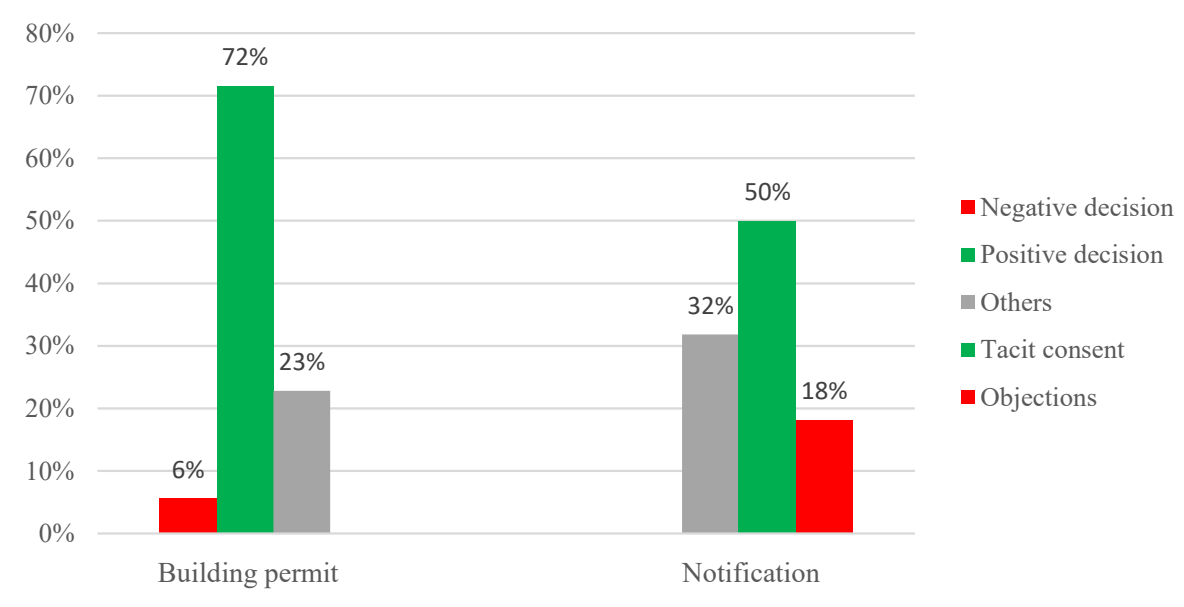

Fig. 12. Outcome of proceedings to obtain permits for the construction of detached single-family residential buildings in Białołęka district in the period from 28 June 2015 to 28 June 2018. Source: authors own study

In Białołęka district (similarly to Bielany district) the procedure of submitting notifications on construction of detached single-family houses in the analysed period resulted in a tacit consent of the authority only in $50 \%$ of the cases. Objections were received by $18 \%$ of investors. The proceedings to obtain a building permit in Białołęka district resulted in a positive decision in $72 \%$ of the cases. Only $6 \%$ of investors received a negative decision (Fig. 12).

The collected data allow the conclusion that both in Bielany and Białołęka districts the building permit procedure much more often concluded with a positive decision for the investor (auxiliary question AQ6).

\section{Summary and conclusion}

Basing on the conducted research, it can be concluded that among the analysed indicators, the only benefit brought to investors by the amendment to the provisions of the Construction Law of 20 February 2015 [3], was the possibility of faster commencement of construction of detached single-family residential buildings (AQ5), which, however, due to the low interest in the procedure (AQ4) and the low rate of positive outcome (AQ2), provided advantages to a negligible group of investors. The amendment did not result in a reduction of the required formalities (AQ1). Expectations that the simplified notification procedure would be used to large numbers turned out to be unjustified. Investors, who had already decided to submit notifications in the area of the capital city of Warsaw, obtained silent consent only in $47 \%$ of the cases. Therefore, most of them, after receiving a decision on objection or withdrawal of notification, were forced to reapply, which obviously involved loss of time, contrary to assumptions of the amended act in this scope.

In both surveyed Warsaw districts, the investors used the notification procedure much less frequently than the traditional building permit procedure (AQ4). In Bielany district, only 16 notifications were submitted while the number of applications for building permits was as high as 108. In Białołęka district, 338 investors used the building permit procedure, while only 110 made use of notifications. 
In the analysed districts, positive decisions were much more frequent among investors who decided to go for the building permit procedure (AQ6). In both Bielany and Białołęka districts, only $50 \%$ of the submitted notifications received a tacit approval of an architecture-construction administrative body, while about $70 \%$ of those applying for a building permit obtained a positive decision. The most common reason for objection to a notification for the construction of detached single-family residential buildings in the period from 28 June 2015 to 28 June 2018 in the area of the capital city of Warsaw was the area of impact of the designed building exceeding the boundaries of a development plot.

Basing on the results of the conducted research, it can be concluded that the amendment to the provisions of the Construction Law Act, coming into force on 28 June 2015, which involves enabling construction of detached single-family residential buildings on the basis of the notification, has not contributed to the improvement of the development process on the territory of the Capital City of Warsaw (GQ). Therefore, the results of this study provide a significant premise for the conclusion that the assumed objectives of the amendment to the Construction Law made on 20 February 2015 have not been achieved [3].

\section{References}

[1] The Act of 7 July 1994, The Construction Law, Warszawa, Journal of Laws 2018, item 1202 as amended.

[2] Niewiadomski Z. (ed.), Prawo budowlane. Komentarz. Warszwa: C.H. Beck, 2018.

[3] Act of 20 February 2015, amending the Construction Law and certain other acts, Warszawa, Journal of Laws 2015, item 443.

[4] Sługocka M., Bursztynowicz M., "Kilka uwag przed wejściem w życie ustawy z dnia 20 lutego 2015 r. nowelizującej prawo budowlane", in: Kępa M., Marszał M. (ed.), Duch praw w krajach Europy Środkowo-Wschodniej. Wydział Prawa, Administracji i Ekonomii Uniwersytetu Wrocławskiego: Wrocław, 2016.

[5] Judgment of the Constitutional Tribunal of 20 April 2011, ref. Kp 7/09 (MP 2011 No 33 item 394).

[6] Piasecka-Sobkiewicz M., "Mniej obowiązków związanych z rozpoczęciem budowy”, Dziennik Gazeta Prawna, 21 May 2015.

[7] Ludwikowski J., "Prostsza droga do własnych czterech kątów”. Dziennik Gazeta Prawna, 12 May 2016.

[8] Nieroda B., Gwizdak W., “Mitomania zgłoszeń”, Zawód: Architekt, Izba Architektów Rzeczypospolitej Polskiej, no. 47 (2015).

[9] Prezydent RP podpisał nowelizację Prawa budowlanego. Muratorplus.pl, 17 March 2015.

[10] Suchodolska M., "Prawo budowlane? Chce mnie pani rozjuszyć!" (an interview with Wojciech Gwizdak), Dziennik Gazeta Prawna, 28 February 2015.

[11] Krupa-Dąbrowska R., "Trzeba samemu skalkulować, co się bardziej opłaca”, Rzeczpospolita, 3 September 2015.

[12] Krzyżanowska A., Żuchowski T., "Domy jednorodzinne na zgłoszenie - ostatnia próba”, Rzeczpospolita, 27 October 2017.

[13] Baniak S., Prawo budowlane oraz proces inwestycji budowlanych. Szczecin: Wyższa Szkoła Administracji Publicznej w Szczecinie, 2019.

[14] Bernatowicz Ł., Nosiński M., Prawo budowlane od dnia 28 czerwca 2015 r. Szczegółowy komentarz do zmian. Gdańsk: Wydawnictwo ODDK, 2015.

[15] Regulation of the Minister of Infrastructure of 12 April 2002 on the technical conditions to be met by buildings and their location (Journal of Laws 2015, item 1422 as amended). 
[16] Judgment of the Supreme Administrative Court of 28 July 2015, ref. II OSK 3089/13.

[17] Judgment of the Supreme Administrative Court of 6 June 2013, ref. II OSk 332/12.

[18] Bielecki M., Proces inwestycyjno-budowlany-aspekty prawne. 2nd edition, Warszawa: C.H. Beck, 2016.

[19] GUNB 2019. Available: http://wyszukiwarka.gunb.gov.p1/ [Accessed: 22 May 2019]

[20] Wielgo M., "Adamczyk miał rację. Zaskakujące dane o budowie domów na podstawie zgłoszenia", Gazeta Wyborcza, 17 February 2016.

[21] Krzyżanowska A., "Upadek domów na zgłoszenie”, Dziennik Gazeta Prawna, 29 August 2016.

[22] Krupa-Dąbrowska R., "Pozwolenie na budowę czy zgłoszenie? Inwestorzy wolą z pozwoleniem", Rzeczpospolita, 20 February 2017.

[23] Krupa-Dąbrowska R., "Willa na zgłoszenie to wciąż wielka rzadkość”, Rzeczpospolita, 1 November 2018. 